\title{
Sensory Disturbance as a Characteristic Symptoms of Methylmercury Poisoning in Niigata, Japan
}

\author{
Hisashi Saito $^{1}$, Kimio Maruyama ${ }^{2}$ and Naoji Hagino ${ }^{3}$ \\ 1. Pediatrician and Internist, Kido Hospital, Niigata 950-0862, Japan \\ 2. Department of Social Welfare, the Niigata Seiryo University, Niigata 951-8121, Japan \\ 3. Certified Environmental Measure, Kido Hospital, Niigata 950-0862, Japan
}

Received: November 09, 2015 / Accepted: November 11, 2015 / Published: December 10, 2015

\begin{abstract}
Fifty years have passed from the first official recognition of the methylmercury ( $\mathrm{MeHg}$ ) poisoning in Niigata (so called the second Minamata disease), Japan in 2015. The first case of MeHg poisoning was found in January 1965, when two surveys were carried out for 20,000 inhabitants lived within $15 \mathrm{~km}$ from the mouth of the Agano river. From these surveys, 26 cases (including 5 cases of death) were officially recognized as MeHg poisoning. Moreover, 9 cases who had no symptoms but whose hair mercury concentration were over 200 ppm were found. Within 20 cases, 15 cases are among 26 cases officially recognized as having MeHg poisoning and 5 cases are among 9 cases who had no symptoms but whose hair mercury concentration were over 200 ppm in 1965 . The distal dominant sensory disturbances of the extremities lasted for more than several decades among 20 cases. The sensory disturbance of the bilateral distal extremities could be used as the gold standard for the diagnosis of MeHg poisoning in the exposed areas. The distal dominant sensory disturbance of the extremities is a typical characteristic and important sign of the MeHg poisoning.
\end{abstract}

Key words: Methylmercury, poisoning, sensory disturbance, Minamata disease.

\section{Introduction}

Fifty years have passed from the first official recognition of the $\mathrm{MeHg}$ poisoning in Niigata (so called the second Minamata disease), Japan in 2015.

In Japan, two large scale of methylmercury ( $\mathrm{MeHg}$ ) poisonings by consumption of fish and shellfish which contaminated by $\mathrm{MeHg}$ discharged from a chemical factory (Chisso factory in Minamata and Showa Denko Kanose factory in Niigata) have occurred. The first poisoning occurred around Minamata city in Kumamoto prefecture in the 1950s. In Minamata, the etiologic agent $(\mathrm{MeHg})$ was not acknowledged until three years after the official identification of the exposed cases [1]. A second poisoning was subsequently recognized along the Agano river in Niigata. In Niigata, a factory located in Kanose town

Corresponding author: Hisashi Saito, honorary director, research field: Minamata disease (methylmercury poisoning). about $65 \mathrm{~km}$ from the mouth of the Agano river caused the pollution [2-6]. The factory (Syowa Denko Kanose factory) started to produce acetaldehyde in 1936 (Fig. 1), but production increased markedly in 1959.

Acetaldehyde is used in the production of plastic goods and the production method used inorganic mercury as the catalyst. $\mathrm{MeHg}$ was a by-product and both forms of mercury were released into the environment. The factory stopped acetaldehyde production in January 1965 [7]. When the poisoning was recognized, there were about 2,000 fishermen operating between the mouth of the Agano river and the factory in Kanose town. A great many fishermen made their living on the river, selling and consuming fish and shellfish from the river every day, and supplying the fish to their neighbors. The fish and shellfish of the Agano river were the essential animal protein for the residents $[7,8]$. 


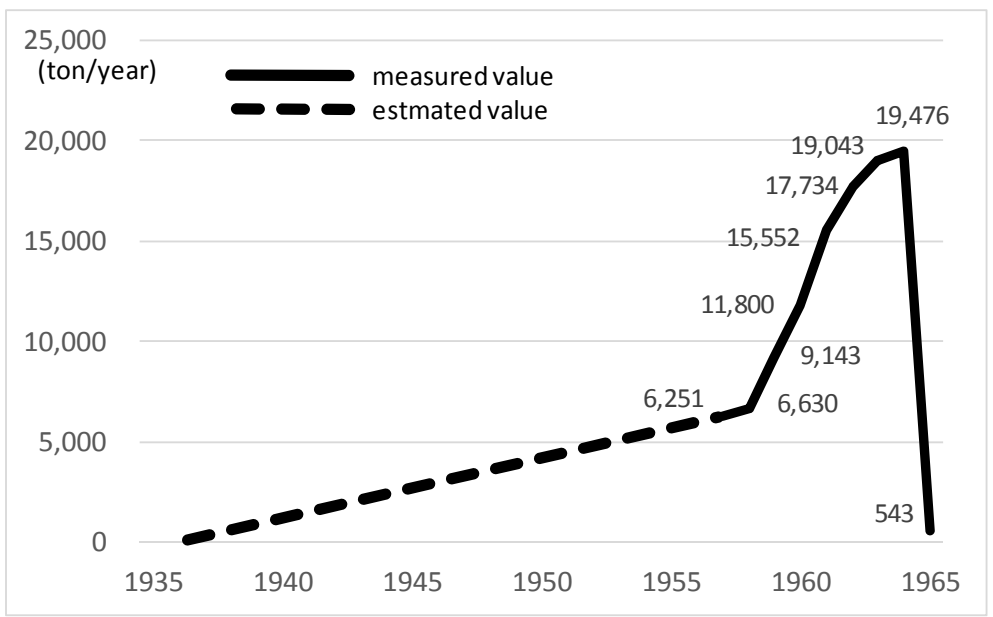

Fig. 1 Acetaldehyde annual amount of production in Showa Denko factory.

Early in 1965 in the Niigata poisoning, there were two extensive surveys of inhabitants living along the Agano river and the adjacent areas, which included assessment of hair $\mathrm{Hg}$ concentration. From these surveys, 26 cases (including 5 cases of death) were officially recognized as having Minamata Disease (MD) based on their subjective symptoms and neurologic signs [2-7] (Table 1). Moreover, 9 cases who had no symptoms but whose hair mercury concentration were over $200 \mathrm{ppm}$ were found [3].

There were 2,979 patients officially recognized as MD patients in the affected prefectures in 2014, however, there are also at least several tens of thousands of exposed patients with neurological signs characteristic of MeHg poisoning who have not been formally recognized as MD patients and not properly compensated $[9,10]$. Although 50 years have passed from the first official recognition of the $\mathrm{MeHg}$ poisoning in Niigata, all the details of the damage caused by MeHg exposure have not yet been brought to light. Several lawsuits are still underway, diagnosis of $\mathrm{MeHg}$ poisoning is the point at issue.

The authors reported 20 cases that they could observe for a long period, 15 cases among 26 cases (including 5 cases of death) were officially recognized as having MD and 5 cases among 9 cases had no symptoms but whose hair mercury concentration were over $200 \mathrm{ppm}$ in 1965. Twenty cases were evaluated during 7-49 years. There are no reports that observed such a long period. These findings would be valuable.

\section{Material and Methods}

\subsection{Studied Area and Participants}

In Niigata, Japan, the first case of MeHg poisoning was found in January, the second in April, and the third in May of 1965. Seven patients were confirmed before June and all lived around the lower stream of the Agano river. Their exposure was due to consumption of fish and shellfish contaminated by $\mathrm{MeHg}$ discharged from a chemical factory (Showa Denko Kanose factory) located on the upper reaches of the Agano river. The total mercury content of fish samples collected in June 1965 from the Agano river was elevated (barbel: 21.0-23.6 ppm, snakehead mullet: 12.3 ppm and chub: 4.6-8.38 ppm) [2, 3, 11].

In June 1965, two surveys were carried out for about 20,000 inhabitants lived within $15 \mathrm{~km}$ from the mouth of the river where the seven patients lived. From these surveys, about 1,300 persons were identified as being exposed, their total hair mercury concentration was measured, and as mentioned above, 26 cases were officially recognized as having MD, and 9 cases whose hair mercury concentration were over $200 \mathrm{ppm}$ but had no symptoms. Tsubaki et al. [3] classified these 26 patients as follows: dead cases: 
Table 1 Neurological signs and symptoms among 26 cases (including 5 cases of death) officially recognized as having Minamata disease in 1965.

\begin{tabular}{|c|c|c|c|c|c|c|c|c|c|c|c|c|c|c|c|c|c|c|c|c|}
\hline \multirow{2}{*}{$\begin{array}{l}\text { Case } \\
\text { No. }\end{array}$} & \multirow{2}{*}{ Age/Sex } & \multirow{2}{*}{ severity } & \multirow{2}{*}{$\begin{array}{l}\text { Hg in } \\
\text { hair } \\
\text { (ppm) }\end{array}$} & \multicolumn{2}{|c|}{$\begin{array}{c}\text { Sensory } \\
\text { disturbance }\end{array}$} & \multirow{2}{*}{$\begin{array}{l}\text { Visual } \\
\text { - constrictio } \\
\mathrm{n}\end{array}$} & \multirow{2}{*}{$\begin{array}{l}\text { Hearing } \\
\text { disturbanc } \\
\mathrm{e}\end{array}$} & \multirow{2}{*}{$\begin{array}{l}\text { Speech } \\
\text { disturbanc } \\
\mathrm{e}\end{array}$} & \multirow{2}{*}{$\begin{array}{l}\text { Gait } \\
\text { disturbance }\end{array}$} & \multirow{2}{*}{$\begin{array}{l}\text { Adiado- } \\
\text { chokinesia }\end{array}$} & \multirow{2}{*}{$\begin{array}{l}\text { Finger } \\
\text { nose } \\
\text { Test }\end{array}$} & \multirow{2}{*}{$\begin{array}{l}\text { Romberg } \\
\text { sign }\end{array}$} & \multirow{2}{*}{$\begin{array}{l}\text { Tremor } \\
\text { at rest }\end{array}$} & \multirow{2}{*}{$\begin{array}{l}\text { Tendon } \\
\text { reflex }\end{array}$} & \multirow{2}{*}{$\begin{array}{l}\text { Pathologic } \\
\text { reflexes }\end{array}$} & \multirow{2}{*}{$\begin{array}{l}\text { Motor } \\
\text { weakness }\end{array}$} & \multirow{2}{*}{$\begin{array}{l}\text { Extra } \\
\text { pyramidal } \\
\text { signs }\end{array}$} & \multirow{2}{*}{$\begin{array}{l}\text { autonomic } \\
\text { disturbance }\end{array}$} & \multirow{2}{*}{$\begin{array}{l}\text { Mental } \\
\text { disturbance }\end{array}$} & \multirow{2}{*}{$\begin{array}{l}\text { Convulsive } \\
\text { seizure }\end{array}$} \\
\hline & & & & Superficial & Deep & & & & & & & & & & & & & & & \\
\hline 1 & $63 / \mathrm{M}$ & Died & & + & & ++ & ++ & ++ & + & & & & & & & & & & ++ & $?$ \\
\hline 2 & $19 / \mathrm{M}$ & Died & & ++ & & $?$ & ++ & ++ & ++ & & & & + & $\downarrow$ & + & + & ++ & ? & +++ & + \\
\hline 3 & $58 / \mathrm{M}$ & Died & & + & & $+?$ & ++ & ++ & ++ & & & & & & & & & & ++ & $?$ \\
\hline 4 & $28 / \mathrm{M}$ & Died & 233 & + & $?$ & +++ & +++ & ++ & +++ & ++ & ++ & - & - & $\uparrow+$ & + & - & + & - & ++ & - \\
\hline 5 & $73 / \mathrm{M}$ & Died & & + & & ++ & +++ & ++ & ++ & & & & & & & & & & $-?$ & $?$ \\
\hline 6 & $31 / \mathrm{M}$ & Severe & 320 & + & - & +++ & + & ++ & ++ & ++ & ++ & + & - & $\uparrow \pm$ & + & \pm & - & - & - & - \\
\hline 8 & $63 / \mathrm{M}$ & Moderate & 77 & + & - & + & ++ & - & - & + & + & - & + & $\mathbf{N}$ & - & - & - & - & - & - \\
\hline 9 & $46 / \mathrm{M}$ & Moderate & 177 & + & \pm & - & + & + & \pm & - & - & - & - & $\mathbf{N}$ & - & - & - & - & - & - \\
\hline 10 & $23 / \mathrm{M}$ & Moderate & 528 & + & - & - & - & - & - & \pm & - & - & - & $\mathbf{N}$ & - & - & - & - & - & - \\
\hline 11 & $34 / \mathrm{M}$ & Mild & 145 & + & + & + & + & - & - & - & - & - & - & $\mathbf{N}$ & - & - & - & - & - & - \\
\hline 12 & $63 / \mathrm{M}$ & Mild & 250 & + & + & - & + & - & - & - & - & - & - & $\mathbf{N}$ & - & - & - & - & - & - \\
\hline 13 & $29 / \mathrm{M}$ & Mild & 310 & + & - & - & - & - & - & - & - & - & - & $\uparrow \pm$ & - & - & - & - & - & - \\
\hline 14 & $48 / \mathrm{M}$ & Mild & 258 & + & - & - & - & - & - & - & - & - & - & $\mathbf{N}$ & - & - & - & - & - & - \\
\hline 15 & $39 / \mathrm{M}$ & Mild & 104 & + & - & - & + & - & - & - & - & - & - & $\mathbf{N}$ & - & - & - & - & - & - \\
\hline 17 & $55 / \mathrm{F}$ & Mild & 343 & - & - & - & + & - & - & - & - & - & + & $\downarrow$ & - & - & - & - & $+※$ & - \\
\hline 18 & $59 / \mathrm{M}$ & Mild & 338 & + & \pm & - & + & - & - & - & - & - & - & $\mathbf{N}$ & - & - & - & - & - & - \\
\hline 19 & $38 / \mathrm{M}$ & Mild & 160 & + & - & - & - & \pm & - & - & - & - & - & $\mathbf{N}$ & - & - & - & - & $\pm ※$ & - \\
\hline 20 & $49 / M$ & Mild & 212 & + & - & - & + & - & - & - & - & - & - & $\mathbf{N}$ & - & - & - & - & - & - \\
\hline 21 & $53 / \mathrm{M}$ & Mild & 319 & + & - & - & + & - & - & - & - & - & - & $\mathbf{N}$ & - & - & - & - & - & - \\
\hline 22 & $26 / \mathrm{M}$ & Mild & 213 & + & - & - & - & - & - & - & - & - & - & $\mathbf{N}$ & - & - & - & - & - & - \\
\hline 23 & $59 / \mathrm{M}$ & Mild & 57 & + & + & - & + & - & & - & + & \pm & + & $\mathbf{N}$ & - & - & - & - & - & - \\
\hline 24 & $28 / \mathrm{M}$ & Mild & 116 & - & - & - & - & - & - & - & - & - & \pm & $\uparrow \pm$ & - & - & - & - & - & - \\
\hline 25 & $37 / \mathrm{M}$ & Mild & 425 & + & - & - & - & - & - & - & - & - & - & $\mathbf{N}$ & - & - & - & - & - & - \\
\hline 26 & $24 / \mathrm{F}$ & Mild & 66 & + & + & - & - & - & - & - & \pm & - & - & $\downarrow$ & - & - & - & - & - & - \\
\hline
\end{tabular}

* R: right, L: left, +++ : very strongly positive, ++ : strongly positive, $+:$ positive, \pm : equivocal and $-:$ negative. 
cases (were decided by their present illness), severe form: 2 cases (have subjective and objective severe symptoms), moderate form: 3 cases (were proofed fairly objective symptoms with subjective symptoms) and mild form: 16 cases (have only the subjective symptoms with a few of the objective symptoms).

The authors could observe twenty cases for a long period, 15 cases among above mentioned 26 cases and 5 cases among above mentioned 9 cases from two survey in 1965 are participants in this study.

\subsection{Measurement of MeHg in Hair}

Mercury content in hair samples was measured using the Dithizone method at Niigata University in June 1965 [2-6].

\subsection{Measurement of Outcomes}

In the present study, neurologic signs of 20 participants were evaluated using a standard neurologic examination by one (H.S.) of the authors.

Tactile sensation was estimated using a small paint brush, or Prenova touch test (Semmees-Weinsteinmono filament) and pain sensation was tested using a roulette wheel. Visual fields were examined by confrontation test. Hearing impairment was examined by tuning fork of $512 \mathrm{~Hz}$ and a ticking watch. Speech disturbances were examined by phonation of labial and lingual sounds. Ataxia was determined by 3 tests: adiadochokinesis, finger nose and heel knee. Disequilibrium was tested by 3 tests: Romberg test, Mann test and standing on one foot. Mann test is used to investigate the loss of balance. The procedure of Mann test is as follows: the subject stands with both legs on a straight line putting the big toe behind the heel of the other foot, and looks straight ahead with eyes open and then closes both eyes. The subject repeats the procedure reversing the positions of his feet. Mann test is judged positive when the subject sways. The participants were all examined between October 1965 and August 2009.

\section{Results}

The demographic characteristics, hair mercury and passage of neurologic signs among 20 cases are shown in Table 2.

First, in 15 cases which officially recognized as having MD, in the first evaluation of sensory disturbance of bilateral extremities, 2 cases (case $\mathrm{J}$ and O) were negative. But then became to be positive and continued. In the other 13 cases, distal dominant sensory disturbance of bilateral extremities continued until the third evaluation.

On the passage of their perioral sensory disturbance, 3 times $(+)$ are 3 cases, namely: case A (severe, 320 ppm), case B (severe, 570 ppm) and case I (mild, 275 ppm). On the other hand, all (-) cases at 2 times or 3 times examination were 6 cases, namely: case $\mathrm{C}$ (moderate, 177 ppm), case E (mild, 145 ppm), cases H (mild, 104 ppm), case N (mild, 213 ppm), case Q (mild, $260 \mathrm{ppm}$ ) and case T (mild, $275 \mathrm{ppm}$ ).

The severe form (case A and case B) had many symptoms, namely: sensory disturbance of the extremities and perioral area, visual constriction, hearing disturbance, speech disturbance, gait disturbance, incoordination and disequilibrium, which are all positive. And in the severe form, they were more severe than in moderate form in the visual constriction, hearing disturbance, speech disturbance, gait disturbance, incoordination, and disequilibrium. However, in the mild cases, these symptoms show some variations that can also worsen or improve, but the sensory disturbance in the extremities consistently is unchanged and lasted several decades.

Second, 5 cases had no symptoms but whose hair mercury concentration were over $200 \mathrm{ppm}$ are as follows.

Case P was a 49 year-old male and his hair mercury value was $378 \mathrm{ppm}$ in June 1965. He realized the general malaise in summer of 1964. He has had blurred vision, numbness in his both feet in 1965, has pointed out the sensory disturbance in extremities and perioral area, back pain, incoordination, and visual 
Table 2 The demographic characteristics, hair mercury, and passage of neurologic signs among 20 cases.

\begin{tabular}{|c|c|c|c|c|c|c|c|c|c|c|c|c|c|c|c|c|c|c|}
\hline \multirow{3}{*}{$\begin{array}{l}\text { Case/Sex } \\
\text { Severity } \\
\begin{array}{l}\text { (Hair mercury in } \\
\text { June 1965) }\end{array} \\
\end{array}$} & \multirow{3}{*}{$\begin{array}{l}\text { Case } \\
\text { number } \\
\text { in Table } \\
1\end{array}$} & \multirow{3}{*}{$\begin{array}{l}\text { Date } \\
\text { symptom } \\
\text { began }\end{array}$} & \multirow{3}{*}{$\begin{array}{l}\text { Age in years } \\
\text { of } \\
\text { assessment } \\
\text { of neurologic } \\
\text { signs }\end{array}$} & \multicolumn{3}{|c|}{ Sensory disturbance } & \multirow{3}{*}{$\begin{array}{l}\text { Visual } \\
\text { constriction }\end{array}$} & \multirow{3}{*}{$\begin{array}{l}\text { Hearing } \\
\text { disturbance }\end{array}$} & \multirow{3}{*}{$\begin{array}{l}\text { Gait } \\
\text { disturbance }\end{array}$} & \multirow{3}{*}{$\begin{array}{l}\text { Speech } \\
\text { disturbance }\end{array}$} & \multicolumn{3}{|c|}{ Incoordination } & \multicolumn{5}{|c|}{ Disequilibrium } \\
\hline & & & & & of Perioral & & & & & & \multirow{2}{*}{$\begin{array}{l}\text { Adido- } \\
\text { cho- } \\
\text { kinesis }\end{array}$} & \multirow{2}{*}{$\begin{array}{l}\text { Finger } \\
\text { nose } \\
\text { test }\end{array}$} & \multirow{2}{*}{$\begin{array}{l}\text { Knee } \\
\text { heel test }\end{array}$} & \multirow{2}{*}{$\begin{array}{l}\text { Romberg } \\
\text { test }\end{array}$} & \multicolumn{2}{|l|}{ Mann test } & \multicolumn{2}{|c|}{ Standing on one foot } \\
\hline & & & & extremities & $\mathrm{s}$ area & area & & & & & & & & & Eyes open & Eyes closed & Eyes open & Eyes closed \\
\hline Case $\mathrm{A} / \mathrm{M}$ & 6 & & 52 & + & + & & +++ & + & ++ & + & ++ & ++ & ++ & + & \pm & ++ & + & + \\
\hline severe form & & Oct. 1964 & 60 & + & + & & +++ & + & ++ & + & + & \pm & \pm & - & ++ & Impossible & ++ & Impossible \\
\hline (320 ppm) & & & 76 & - & + & & +++ & + & ++ & + & + & + & + & + & Impossible & Impossible & Impossible & Impossible \\
\hline Case B/M & 7 & & 56 & + & + & & +++ & ++ & + & ++ & + & + & + & + & & & & \\
\hline severe form & & $\begin{array}{l}\text { April. } \\
1965\end{array}$ & 72 & + & + & & +++ & ++ & ++ & ++ & ++ & & & Impossible & Impossible & Impossible & Impossible & Impossible \\
\hline (570 ppm) & & & 76 & + & + & & & + & ++ & ++ & ++ & + & + & Impossible & Impossible & Impossible & Impossible & Impossible \\
\hline Case $\mathrm{C} / \mathrm{M}$ & 9 & & 51 & + & + & & + & & + & + & $\mathrm{R} \pm, \mathrm{L}-$ & + & + & & & & & \\
\hline moderate form & & Oct. 1964 & 68 & + & - & Left side & & & + & + & & & & & & & & \\
\hline (177 ppm) & & & 70 & + & & Left side & & + & + & + & - & - & - & - & & & & \\
\hline Case D/M & 10 & & 38 & + & + & & & & - & - & + & - & - & - & - & \pm & - & \pm \\
\hline mild form & & Nov. 1964 & 44 & + & + & & + & - & - & - & + & - & - & - & - & + & - & + \\
\hline (528ppm) & & & 59 & + & - & & \pm & + & - & - & + & - & - & - & - & + & \pm & + \\
\hline Case E/M & 11 & & 35 & + & & & + & + & - & - & - & - & - & - & & & & \\
\hline mild form & & Nov. 1964 & 39 & + & - & & + & - & - & - & & & & \pm & \pm & & & since about 65 \\
\hline (145 ppm) & & & 71 & + & - & Left side & \pm & ++ & + & & + & $\mathrm{L}+$ & $\mathrm{L}+$ & + & Impossible & Impossible & Impossible & yrs old \\
\hline Case F/M & 12 & & 63 & + & - & & - & - & - & - & - & - & - & - & - & & + & \\
\hline mild form & & Feb. 1965 & 74 & + & + & & + & + & & \pm & + & $\mathrm{R} \pm, \mathrm{L}+$ & $\mathrm{R} \pm, \mathrm{L}+$ & & ++ & & & \\
\hline (250 ppm) & & & 81 & + & - & & + & + & & \pm & \pm & \pm & \pm & & & & & \\
\hline Case G/M & 13 & & 46 & + & + & & - & \pm & - & \pm & \pm & \pm & \pm & - & & & & \\
\hline mild form & & $\begin{array}{l}\text { April. } \\
1965\end{array}$ & 60 & + & - & & - & + & - & - & \pm & - & - & - & - & + & - & + \\
\hline (310 ppm) & & & 66 & + & + & & - & + & - & - & - & - & - & - & - & \pm & + & ++ \\
\hline Case $\mathrm{H} / \mathrm{M}$ & 15 & & 49 & + & & & - & + & - & - & - & - & - & - & & & & \\
\hline mild form & & Feb. 1965 & 53 & + & - & $\begin{array}{l}\text { Right } \\
\text { side }\end{array}$ & - & - & - & \pm & $\mathrm{R} \pm \mathrm{L}-$ & $\mathrm{R} \pm \mathrm{L}^{-}$ & $\mathrm{R} \pm, \mathrm{L}-$ & & & & & \\
\hline (104 ppm) & & & 56 & + & - & $\begin{array}{l}\text { Right } \\
\text { side }\end{array}$ & - & - & - & \pm & $\mathrm{R}+, \mathrm{L}-$ & $\mathrm{R}+, \mathrm{L}-$ & $\mathrm{R}+, \mathrm{L}-$ & & & & & \\
\hline Case I/F & 16 & & 62 & + & + & Left side & - & + & - & - & - & - & - & - & - & + & - & + \\
\hline mild form & & $\begin{array}{l}\text { May or } \\
\text { Jun. } 1965\end{array}$ & 68 & + & + & & - & + & & - & - & - & - & - & - & \pm & - & + \\
\hline (275 ppm) & & & 76 & + & + & & - & +++ & + & - & - & - & - & - & + & Impossible & Impossible & Impossible \\
\hline Case $\mathrm{J} / \mathrm{F}$ & 17 & & 56 & - & - & & - & + & - & - & - & - & - & - & + & & - & Parkinsonism \\
\hline mild form & & 1962 & 65 & + & + & & \pm & + & & \pm & + & \pm & \pm & & + & & & since about 60 \\
\hline (343 ppm) & & & 66 & + & + & & + & - & - & - & - & \pm & \pm & & & & & \\
\hline
\end{tabular}




\begin{tabular}{|c|c|c|c|c|c|c|c|c|c|c|c|c|c|c|c|c|c|c|}
\hline Case K/M & 18 & & 70 & + & + & & + & + & - & - & ++ & \pm & \pm & - & + & & + & \\
\hline mild form & & 1962 & 73 & + & - & & - & + & - & - & + & + & + & \pm & & & + & \\
\hline (338ppm) & & & 79 & + & - & & - & ++ & - & - & + & - & - & - & - & \pm & $\mathrm{R}+, \mathrm{L}-$ & $\mathrm{R}++, \mathrm{L}+$ \\
\hline Case L/M & 20 & & 50 & + & + & & - & + & - & - & - & - & - & - & & & & \\
\hline mild form & & $\begin{array}{l}\text { Spring } \\
1964\end{array}$ & 61 & + & + & & - & $\mathrm{L}+$ & - & \pm & + & - & - & & + & & & \\
\hline (212ppm) & & & 67 & + & - & & & - & - & - & - & - & - & & & & & \\
\hline Case M/M & 21 & & 55 & + & - & & - & + & - & - & - & - & - & - & & & & \\
\hline mild form & & $\begin{array}{l}\text { May. } \\
1965\end{array}$ & 67 & + & + & & \pm & + & - & - & $\mathrm{L} \pm$ & - & - & & + & & & \\
\hline (319ppm) & & & 71 & + & - & & - & $\mathrm{L} \pm$ & - & - & $\mathrm{L}^{ \pm}$ & \pm & \pm & & + & & & \\
\hline Case N/M & 22 & & 27 & + & - & & - & - & - & - & - & - & - & - & - & & + & \\
\hline mild form & & $\begin{array}{l}\text { May. } \\
1965\end{array}$ & 56 & + & & & - & - & - & - & - & - & - & - & - & \pm & - & $\mathrm{R}-, \mathrm{L}+$ \\
\hline (213ppm) & & & 66 & + & - & & - & & - & - & - & - & - & - & - & \pm & - & + \\
\hline Case O/M & 24 & & 28 & - & - & & - & - & - & - & - & - & - & - & & & - & \\
\hline mild form & & Aug. 1964 & 48 & + & + & Left Side - & - & - & & - & + & & & - & + & & + & \\
\hline (116ppm) & & & 69 & + & + & & - & & ++ & - & \pm & + & + & & + & & + & Impossible \\
\hline Case P/M & & & 49 & - & - & & - & - & - & - & - & & - & - & - & & - & \\
\hline no symptoms & & $\begin{array}{l}\text { Summer } \\
1964\end{array}$ & 63 & + & $-\sim \pm$ & & \pm & \pm & - & \pm & \pm & \pm & \pm & & + & & & \\
\hline (378ppm) & & & 80 & + & - & & - & ++ & - & - & - & - & - & - & - & \pm & + & ++ \\
\hline Case Q/F & & & 26 & - & - & & - & - & - & - & - & - & - & - & - & & - & \\
\hline no symptoms & & 1965 & 38 & $\begin{array}{l}\text { Hands } \pm \\
\text { legs }+\end{array}$ & - & & - & - & - & - & - & - & - & - & - & & - & \pm \\
\hline (260ppm) & & & 75 & + & - & & - & - & - & - & - & - & - & - & - & + & - & + \\
\hline Case R/M & & & 48 & - & - & & - & - & - & - & - & - & - & - & - & & - & \\
\hline no symptoms & & 1965 & 64 & + & + & & - & + & - & - & \pm & \pm & \pm & & + & & & \\
\hline (325pm) & & & 70 & + & + & & & + & - & - & - & \pm & + & & - & + & - & + \\
\hline Case S/M & & & 65 & - & - & & - & - & - & - & - & - & - & - & - & & - & \\
\hline no symptoms & & 1965 & 71 & + & + & Left Side & & & + & + & - & + & + & + & Impossible & Impossible & Impossible & Impossible \\
\hline (201ppm) & & & 77 & + & \pm & & & \pm & + & + & \pm & - & - & Impossible & Impossible & Impossible & Impossible & Impossible \\
\hline Case T/M & & & 15 & - & - & & - & - & - & - & - & - & - & - & - & & - & \\
\hline no symptoms & & 1965 & 22 & + & - & & \pm & & - & - & \pm & \pm & \pm & & & & & \\
\hline (275ppm) & & & 30 & + & - & & - & - & - & - & - & - & - & & & & & \\
\hline
\end{tabular}

* R: right, $\mathrm{L}$ : left, +++ : very strongly positive, ++ : strongly positive, $+:$ positive, \pm : equivocal and $-:$ negative. 
constriction in the university hospital in 1969 . He was diagnosed as the $\mathrm{MeHg}$ poisoning patient in 1969. And then he had headaches and blurred vision.

Case $\mathrm{Q}$ is a mother of a congenital $\mathrm{MeHg}$ poisoned child. She has had headaches, her limbs tiredness and pain, and had sensory disturbance in her extremities since 1965, however, she was recognized as having sensory disturbance of her extremities and mild incoordination, and was diagnosed as having MD. She had sensory disturbance of extremities, and her other symptoms were relative mild.

Case $\mathrm{R}$ was a fisherman who had eaten large amounts of fish contaminated by MeHg. He felt the numbness around his perioral and hand fingers in 1965, from that end of the year he has had lumbago, easily tired and lost perseverance, and became to be sensitive to cold. In 1966, he had numbness and cold feeling in his legs, and also had numbness in bilateral hands and perioral area, from this time he became easily stumble. In February 1967, his grasping power had gone down and he had incoordination, he was diagnosed as MD.

Case $\mathrm{S}$ was engaged in his own bicycle shop around the Agano river, and he had received a lot of the fish from several customers almost every day. So, he had eaten the fish every day. Since October 1965, he sometimes felt he had muscle cramp in his breast, pain in his hands and had numbness in his perioral area and bilateral fingers. In November 1965, he received the medication of the excretion drug for mercury at the hospital. After the onset of the illness, his symptoms had become continuous, and in-coordination of his limbs appeared, disequilibrium, contracture of the hands, the tinnitus and hearing impairment etc. He had had the sensory disturbance of his extremities and had been found to have moderate visual constriction and be diagnosed as $\mathrm{MeHg}$ poisoning in 1969.

Case $\mathrm{T}$ was a teenage male, his work was the transportation of timber, but had not power as to be laughed by some females. And he didn't go holiday anywhere, and just lay in the house. His elder sister took him to the university hospital, but the objective symptoms was not presenting. In 1969, finally, the sensory disturbance in the extremities, mild visual constriction also pointed out, and he was diagnosed as the $\mathrm{MeHg}$ poisoning.

These 5 cases had no symptoms but whose hair $\mathrm{Hg}$ concentration were over 200 ppm in 1965. However, after several years, neurological symptoms of $\mathrm{MeHg}$ poisoning manifested in all of them, and they were diagnosed as having $\mathrm{MeHg}$ poisoning.

As shown in Table 2, the authors followed up these cases.

Two cases (case E and case J) among 20 cases were diagnosed as Parkinsonism. These 2 cases had muscle rigidity, tremors, walking disorder with frozen gait after 60 years old. Case $\mathrm{J}$ had a mental disorder.

\section{Discussion}

The severe form (case A and case B) had many symptoms, namely: their sensory disturbance of extremities and perioral, visual constriction, hearing disturbance, articulation disorder, gait disturbance, incoordination and disequilibrium, which were all positive. And two cases of the severe form were more severe than moderate form (case C). However, the mild cases were various and also worsen or improve, but the sensory disturbance in the extremities consistently was unchanged and still after several decades year since getting their first sensory disturbance.

Tsubaki pointed out that sensory disturbance tended to appear in the distal extremities, perioral area and tongue, and it was hard to cure as the characteristics of $\mathrm{MeHg}$ poisoning [12]. This opinion is very important and worthy of note. It is applicable to this survey. In this study, all cases had sensory disturbance of the extremities that lasted several decades. The persisting somatosensory disorders after the discontinuation of exposure to $\mathrm{MeHg}$ are thought to be induced by diffuse damage to the somatosensory cortex [13].

The severe form of cases had poor coordination, and poor equilibrium than the moderate form and mild 
Table 3 The number of persons who were exposed to MeHg, had sensory disturbance of the extremities [9].

\begin{tabular}{lllll}
\hline & & Minamata area & Niigata area & Total \\
\hline A & Official recognized MD (the compensation) & 2,277 & 702 & 2,979 \\
B & MD victims under the political settlement & 43,558 & 2,781 & 46,339 \\
& Total & 45,835 & 3,483 & 49,318 \\
\hline
\end{tabular}

* A: Persons recognized as Minamata disease patients under the Pollution-Related Health Damage Compensation System; B: Persons who received relief as MD victims under the political settlement.

form of cases. From a pathological study in $\mathrm{MeHg}$ poisoning cases, it is confirmed that the severe $\mathrm{MeHg}$ poisoning patients have severe cerebellar symptoms, but the moderate or mild $\mathrm{MeHg}$ poisoning patients have relative mild cerebellar lesion or nothing [14].

As shown in Table 3, there are around 50,000 persons who were officially recognized MD (A) and MD victims under the political settlement (B), they were all exposed to $\mathrm{MeHg}$, and have sensory disturbance of extremities in Japan at present. Thus, although there is criticism that the evaluation of sensory disturbance using a small paint brush and roulette wheel is not objective and untrustworthy. In Japan, using standard neurological examination around 50,000 persons were recognized having sensory disturbance of extremities.

Furthermore, several studies in non-MeHg-exposed residents in Japan demonstrated that prevalence of sensory disturbance of the extremities ranged from $0 \%$ to $1.1 \%$. The prevalence of sensory disturbance of the bilateral distal extremities in the MeHg-exposed residents around the Minamata bay were about 30\%, and in the polluted area near Minamata bay, the attributable risk percent is over $99 \%$. Therefore, the Japanese Society of Psychiatry and Neurology noted that sensory disturbance of the bilateral distal extremities could be used as the gold standard for diagnosis of MD in MeHg exposed areas [15, 16].

However, in 5 cases had no symptoms but whose hair $\mathrm{Hg}$ concentration were over $200 \mathrm{ppm}$, the $\mathrm{MeHg}$ poisoning symptoms manifested long after exposure to $\mathrm{MeHg}$ has ceased.

It had been considered that if the exposure to $\mathrm{MeHg}$ has ceased, the poisoning symptoms do not develop more severely, and then improve, because the half-life of $\mathrm{Hg}$ in the human body is about 70 days. Overt symptoms of $\mathrm{MeHg}$ poisoning can be manifested after over 10 years exposure to $\mathrm{MeHg}$ has ceased [17, 18]. It is confirmed by animal experiment that overt symptoms of the poisoning develops many years after the cessation of $\mathrm{MeHg}$ exposure [19, 20]. At present, it is confirmed that the delayed neurotoxicity and delayed onset MD exist.

In this study, the Parkinsonism was diagnosed in 2 out of 20 cases who were officially recognized as having MD. These 2 cases had muscle rigidity, tremors, walking disorder with frozen gait after 60 years old. Case $\mathrm{J}$ had a mental disorder with $\mathrm{MeHg}$ poisoning. The problem about the association between Parkinsonism and MeHg exposure should be solved in future.

\section{Conclusion}

Twenty cases who followed up from 15 cases among 26 cases (including 5 cases of death) officially recognized as having MD and 5 cases among 9 cases with no symptoms and over 200 ppm of hair mercury concentration were surveyed for a long period. The distal dominant sensory disturbances of extremities lasted several decades, and is a typical characteristic and important sign of the $\mathrm{MeHg}$ poisoning.

\section{Acknowledgments}

This study was approved by the ethics committee of Kido hospital.

Making use the clinical charts by Dr. Kenichi Shirakawa, Dr. Kouichi Hirota, Dr. Hitoshi Hama and many Kido hospital staff, and many patients 
responded this survey were much appreciated.

\section{References}

[1] Harada, M. 1995. "Minamata Disease: Methylmercury Poisoning in Japan Caused by Environmental Pollution." Crit. Rev. Toxicol. 25: 1-24.

[2] Tsubaki, T. 1979. "Clinical Epidemiology about Niigata Minamata Disease." In Minamataaisease, Researches during 20 Years and the Problems at Present, edited by Arima, S. Tokyo: Seirinsha.

[3] Ministry of Health and Welfare. 1967. Research on Diagnosis of the Mercury Poisoning. Tokyo: Ministry of Health and Welfare.

[4] Tsubaki, T. 1968. "Organic Mercurial Poisoning along the Agano River." Internal Medicine 21: 871-875.

[5] Tsubaki, T. 1968. "Methylmercury Poisoning along the Agano River, Researches by Niigata University." Clinical Neurology 8: 511-520.

[6] Tsubaki, T. 1972. "The Follow up of Niigata Minamata Disease." Science 42: 526-531.

[7] Saito, H. 2009. The Agano River and Water Contamination. Niigata: Niigata Nippo Jigyosha.

[8] Niigata Prefecture Department of Welfare and Public Health. 2002. "Outline of Niigata Minamata Disease." Niigata: Niigata Prefectural Government Office.

[9] Association of Accusation against Minamata Incident. 2015. "The Number of Minamata Disease Victims." Tokyo News for Supporting the Minamata Disease Victims 72: 3.

[10] Yorifuji, T., Tsuda, T., and Harada, M. 2013. "Chapter 5: Minamata Disease: A Challenge for Democracy and
Justice, Late Lessons from Early Warnings: Science, Precaution and Innovation." European Environment Agency 1: 92-130.

[11] Ministry of Health and Welfare. 1967. "Epidemiological Research on the Mercury Poisoning." In Special Research Report on Organic Mercury Poisoning in Niigata, 1-53.

[12] Tsubaki, T., Shirakawa, K., Kanbayashi, K., and Hirota, K. 1969. "Clinical Features of Organic Mercury Intoxication in Agano River." Advances in Neurological Sciences 13 (1): 85-88.

[13] Ekino, S. 2000. Opinion about Methylmercury Poisoning. Fukuoka: Ashi Publisher.

[14] Takeuchi, T., and Eto, K. 1979. Pathological Outline of Minamata Disease. Tokyo: Seirinsha.

[15] Tsuda, T. 1999. “Opinion's Note on the Minamata Disease. Fukuoka: Ashi Publisher.

[16] The Committee on Research Human Right in the Japanese Society of Psychiatry and Neurology. 1998. "An Opinion on the Criteria on Acquired Minamata Disease." Psychiatriaet Neurologia Japonica 100: 765-790.

[17] Igata, A., Shinna, K., and Hamada, R. 1976. "Delayed Minamata Disease.” Igaku No. Ayumi 96 (13): 890-894.

[18] Fujino, T., Itai, Y., and Motomatsu, Y. 1988. "The Study of the Small Amount Pollution by MeHg, Japanese." Medical Review 84: 46-54.

[19] Berlin, M., Grant C. A., Hellberg, J., Hellström, J., and Schultz, A. 1975. "Neurotoxicity of Methylmercury in Squirrel Monkeys." Arch. Environ. Health 30: 340-348.

[20] Rice, D. C. 1996. "Evidence for Deleyed Neurotoxicity Produced by Methylmercury." Neurotoxicology 17: 583-596. 